\title{
THE EFFECT OF THE ANTIOXIDANT DRUG U-74389G ON URIC ACID LEVELS DURING ISCHEMIA REPERFUSION INJURY IN RATS
}

Constantinos Tsompos ${ }^{1}$, Constantinos Panoulis ${ }^{2}$, Konstantinos Toutouzas ${ }^{3}$, Aggeliki Triantafyllou ${ }^{4}$, George Zografos ${ }^{5}$, Apostolos Papalois ${ }^{6}$ ${ }^{1}$ Department of Obstetrics \& Gynecology, Mesologi County Hospital, Etoloakarnania, Greece

${ }^{2}$ Department of Obstetrics \& Gynecology, Aretaieion Hospital, Athens University, Attiki, Greece ${ }^{3}$ Department of Surgery, Ippokrateion General Hospital, Athens University, Attiki, Greece ${ }^{4}$ Department of Biologic Chemistry, Athens University, Attiki, Greece

${ }^{5}$ Department of Surgery, Ippokrateion General Hospital, Athens University, Attiki, Greece

${ }^{6}$ Experimental Research Centre ELPEN Pharmaceuticals, S.A. Inc., Co., Attiki, Greece

\section{EFEKTI ANTIOKSIDACIONOG LEKA U-74389G \\ NA VREDNOSTI MOKRACNE KISELINE TOKOM \\ ISHEMIJSKO REPERFUZIONE POVREDE KOD PACOVA}

\author{
Constantinos Tsompos ${ }^{1}$, Constantinos Panoulis ${ }^{2}$, Konstantinos Toutouzas ${ }^{3}$, Aggeliki Triantafyllou ${ }^{4}$, George Zografos ${ }^{5}$, Apostolos Papalois ${ }^{6}$ \\ ${ }^{1}$ Klinika za ginekologiju i akušerstvo, Klinički centar Mesologi, Etoloakarnania, Grčka \\ ${ }^{2}$ Odeljenje za ginekologiju i akušerstvo, Aretaieion bolnica, Univerzitet u Atini, Attiki, Grčka \\ ${ }^{3}$ Klinika za hirurgiju, Ippokrateion Bolnica, Univerzitet u Atini, Attiki, Grčka \\ ${ }^{4}$ Katedra za Biološku hemiju, Univerzitet u Atini, Attiki, Grčka \\ ${ }^{5}$ Klinika za hirurgiju, Ippokrateion Bolnica, Univerzitet u Atini, Attiki, Grčka \\ ${ }^{6}$ Centar za farmaceutska eksperimentalna istraživanja ELPEN, S.A. Inc. co., Atikki, Grčka
}

\begin{abstract}
This experimental study examined the effect of the antioxidant drug U-74389G in a rat model using a renal ischaemia-reperfusion (IR) protocol. The effects of the molecule were studied biochemically by assessing mean serum uric acid levels (SUA). In total, 40 rats (mean weight $=231.875$ g) were used in the study. SUA levels were measured at 60 min of reperfusion for groups $A$ and $C$ and at 120 min of reperfusion for groups $B$ and $D$. The drug $U-74389 G$ was administered only in groups $C$ and D. U-74389G administration non-significantly increased the SUA levels by $15.43 \% \pm 9.10 \%(p=0.096)$ at the representative endpoint of $1.5 \mathrm{~h}$. The reperfusion time non-significantly decreased the SUA levels by $13.61 \% \pm 9.18 \%(p=0.126)$. However, the interaction of U-74389G administration and reperfusion time non-significantly increased the SUA levels by $4.78 \% \pm 5.64 \%$ $(p=0.387)$. Whether it interacted with the reperfusion time, U-74389G administration non-significantly increased SUA levels. It seems that U-74389G cannot reverse injury to IR tubular epithelial cells within 2 hours.
\end{abstract}

Keywords: ischaemia, U-74389G, uric acid, reperfusion

\section{SAŽETAK}

$U$ ovoj eksperimentalnoj studiji ispitivani su efekti antioksidacionog leka U-74389G tokom ishemije i reperfuzije bubrega na modelu pacova. Efekti ispitivanog molekula su izučavani biohemijski, merenjem srednje vrednosti nivoa mokraćne kiseline u serumu. U studiji je korišćeno 40 pacova (prosečna telesna masa $=231,875 \mathrm{~g}$ ). Nivoi mokraćne kiseline u serumu su mereni za grupe $A$ i $C$ u šezdesetom minutu, a za grupe B i D u stodvadesetom minutu reperfuzije. U-74389G je primenjivan samo u grupi C i D. Administracija U-74389G nije dovela do statistički značajnog povećanja niova mokraćne kiseline u krajnjoj tački u devedesetom minutu 15,43\% $\pm 9,10 \%$ ( $p=0,096)$. Reperfuzija nije dovela do statistički značajnog smanjenja nivoa mokraćne kiseline u serumu $13,61 \% \pm 9,18 \%(p=0,126)$. Bez obzira na reperfuziono vreme administracija U-74389G nije statistički značajno povisila nivo mokraćne kiseline u serumu. Izgleda da u toku dva sata U-74389G ne može popraviti povredu tubularnih epitelijalnih ćelija nastalu ishemijom i reperfuzijom.

Ključne reči: ishemija, $U$-74389G, mokraćna kiselina, reperfuzija
IR - ischaemia-reperfusion SUA - serum uric acid SD - standard deviation
L - lazaroid

GLM - generalized linear models

AIS - acute ischaemic stroke 


\section{INTRODUCTION}

Tissue ischaemia-reperfusion (IR) injury can induce permanent or transient damage with serious implications to adjacent organs and systems. The use of U-74389G in IR has been a challenge for many years. However, although progress has been significant, several practical questions have not been clarified. They include:

a) how potent U-74389G should be;

b) when it should be administered; and

c) the optimal dose at which U-74389G should be administered.

The promising effect of U-74389G in tissue protection has been noted in several IR studies. U-74389G, also known as 21-[4-(2,6-di-1-pyrrolidinyl-4-pyrimidinyl)1-piperazinyl]-pregna-1,4,9(11)-triene-3,20-dione maleate salt, is an antioxidant that prevents both arachidonic acidinduced and iron-dependent lipid peroxidation (1). Lazaroids, a novel series of glucocorticoid compounds such as 21 -aminosteroids, promote free radical scavenging. U$74389 \mathrm{G}$ is one of the 132 similar lazaroid compounds. It has a molecular weight of $726.90406 \mathrm{~g} / \mathrm{mol}$ and a selective action on vascular endothelium with vitamin E-like properties. It also exhibits neuroprotection and membrane-stabilizing properties. It protected against IR injury in heart, liver and kidney models. These membrane-associated antioxidants are particularly effective in preventing permeability changes in monolayers of brain microvascular endothelial cells (2). A meta-analysis of 15 published studies, including red blood cell counts, haemoglobin and mean corpuscular haemoglobin levels, platelet count, plateletcrit, platelet distribution width, glucose, total protein, alkaline phosphatase, creatine phosphokinase, sodium, chloride, calcium, phosphorus and magnesium levels, examined in the same experimental setting, provided a total numeric evaluation of the U-74389G anabolic efficacy of approximately $+2.14 \% \pm 7.18 \%$ (p-value $=0.227$ ) at the same endpoints $(3,4)$. Several publications addressed trials of other similar antioxidant molecules to which the studied molecule U-74389G belongs.

The aim of this experimental study was to evaluate the effect of U-74389G in a rat model of renal IR using mean serum uric acid levels (SUA).

\section{MATERIALS AND METHODS}

\section{Animal preparation}

This basic experimental study was licensed by Veterinary Address of East Attiki Prefecture under 3693/12-11- 2010 \& 14/10-1-2012. All consumables, equipment and substances used were grants of the Experimental Research Centre of ELPEN Pharmaceuticals Co. Inc. S.A. at Pikermi, Attiki. Accepted standards of humane animal care were adopted for albino female Wistar rats. Seven days of normal pre-experi- mental housing allowed for an ad libitum diet in the laboratory. In total, 40 female albino Wistar rats (16 -18 weeks old) were used (mean weight \pm standard deviation (SD): $232 \pm 37$ $\mathrm{g}$ ), with a minimum weight of $165 \mathrm{~g}$ and a maximum weight of 320 g. Rats' weights could be a confounding factor; e.g., more obese rats have higher SUA levels. This was also investigated. Post-experimental awakening of animals was not permitted, even if euthanasia was needed. Rats were randomly sorted into four experimental groups with 10 animals in each group using the following IR protocols: ischemia for $45 \mathrm{~min}$ followed by reperfusion for $60 \mathrm{~min}$ (group A); ischaemia for $45 \mathrm{~min}$ followed by reperfusion for $120 \mathrm{~min}$ (group B); ischaemia for 45 min followed by immediate U74389G intravenous (IV) administration and reperfusion for $60 \mathrm{~min}$ (group C); and ischaemia for $45 \mathrm{~min}$ followed by immediate U-74389G IV administration and reperfusion for $120 \mathrm{~min}$ (group D). The dose of U-74389G was $10 \mathrm{mg} / \mathrm{kg}$ body mass. The protocol and doses were determined via the following experiments with favourable outcomes. Flessas I et al. found (5) that the role of U-74389G was protective in many emergency clinical situations of intestinal IR. Bimpis A et al. showed limited brain damage after (6) U-74389G administration. Tsaroucha AK et al. (7) showed attenuated liver damage after U-74389G administration. Andreadou I et al. showed that the small intestine (8) was protected after U-74389G administration.

The detailed prenarcotic and general anaesthesiologic techniques were described previously $(3,4)$. A continuous intra-experimental oxygen supply, electrocardiogram and acidometry were maintained. Ischaemia was caused by laparotomic clamping of the inferior aorta over the renal arteries with forceps for $45 \mathrm{~min}$. Reperfusion was induced by removing the clamp and re-establishing the patency of the inferior aorta. After the exclusion of a blood flow, the IR protocol was applied as described above for each experimental group. U-74389G was administered at the time of reperfusion through the catheterized inferior vena cava. The SUA levels were determined at the 60th min of reperfusion (for the $A$ and $C$ groups) and at the 120th min of reperfusion (for the $B$ and $D$ groups).

\section{Control groups}

Twenty control rats $(252 \pm 39$ g) underwent ischaemia for $45 \mathrm{~min}$ followed by reperfusion.

Group A

Reperfusion lasted for $60 \mathrm{~min}$ ( $\mathrm{n}=10$ control rats, $243 \pm 46$ $\mathrm{g}$ ), and SUA levels were $1.03 \pm 0.176 \mathrm{mg} / \mathrm{dl}$ (Table 1).

Group B

Reperfusion lasted for $120 \mathrm{~min}(\mathrm{n}=10$ control rats, $262 \pm 31 \mathrm{~g}$ ), and SUA levels were $0.95 \pm 0.295 \mathrm{mg} / \mathrm{dl}$ (Table 1).

Groups receiving the lazaroid (L) drug U-74389G

The 20 rats $(211+17 \mathrm{~g})$ receiving $\mathrm{L}$ experienced ischaemia for $45 \mathrm{~min}$ followed by reperfusion after $10 \mathrm{mg}$ of U-74389G / $\mathrm{kg}$ body weight was IV administered. 
Group C

Reperfusion lasted for $60 \mathrm{~min}(\mathrm{n}=10 \mathrm{~L}$ rats, $212 \pm 17 \mathrm{~g})$, and SUA levels were $1.27 \pm 0.457 \mathrm{mg} / \mathrm{dl}$ (Table 1 ).

\section{Group D}

Reperfusion lasted for $120 \mathrm{~min}(\mathrm{n}=10 \mathrm{~L}$ rats, $210 \pm 18 \mathrm{~g})$, and SUA levels were $1.05 \pm 0.201 \mathrm{mg} / \mathrm{dl}$ (Table 1 ).

\section{STATISTICAL ANALYSIS}

Every weight and SUA level group was compared with each other using paired t-tests. Significant differences among SUA levels were investigated. A generalized linear model (GLM) was applied with SUA levels as the dependent variable. The 3 independent variables were: the presence/absence of U-74389G, the reperfusion time, and both variables in combination. Using rat weight as an independent variable in the GLM analysis, a non-significant relationship was detected $(\mathrm{p}=0.4431)$, so further investigation was not needed.

\section{RESULTS}

The application of GLM resulted in the following findings: U-74389G administration non-significantly increased SUA levels by $0.17 \mathrm{mg} / \mathrm{dl}[-0.026 \mathrm{mg} / \mathrm{dl}-0.366 \mathrm{mg} /$ $\mathrm{dl}](\mathrm{p}=0.088)$. This finding was in accordance with a paired t-test $(\mathrm{p}=0.103)$. The reperfusion time non-significantly decreased SUA levels by $0.15 \mathrm{mg} / \mathrm{dl}[-0.348 \mathrm{mg} / \mathrm{dl}-0.048$ $\mathrm{mg} / \mathrm{dl}](\mathrm{p}=0.134)$, also in accordance with the results of a paired t-test $(\mathrm{p}=0.118)$. However, $\mathrm{U}-74389 \mathrm{G}$ administration and reperfusion time non-significantly increased SUA levels by $0.052 \mathrm{mg} / \mathrm{dl}[-0.069 \mathrm{mg} / \mathrm{dl}-0.174 \mathrm{mg} / \mathrm{dl}]$ (p= 0.387 ). Tables 2 and 3 summarize the changes in the influence of U-74389G in connection with reperfusion time.

\section{DISCUSSION}

SUA is considered to be a reliable index of renal function. Its production is influenced by ischaemia and by a certain mode. Chiquete E et al. showed (9) that SUA is a potent antioxidant, and its serum concentration increases rapidly after acute ischaemic stroke (AIS). They associated the magnitude of cerebral infarction with the mean SUA concentration and favourable outcomes $(\mathrm{p}=0.004)$ in patients with AIS upon hospital arrival. Logallo $\mathrm{N}$ et al. positively correlated (10) the adjusted SUA level with clinical improvement $(\mathrm{p}=0.02)$ and favourable stroke outcome $(\mathrm{p}=0.04)$ in patients with tissue plasminogen activator thrombolysis upon admission. Seifert $\mathrm{J}$ et al. found (11) SUA levels on day 7 and ribose ingestion after 14 days. Hellsten-Westing Y et al. found (12) that SUA is taken up by the strenuous muscle, which is the main source of plasma hypoxanthine in the blood. SUA is also taken up by the
Table 1: Weight and mean serum uric acid levels and SD of the groups.

\begin{tabular}{|l|l|l|l|}
\hline Groups & Variable & Mean & SD \\
\hline A & Weight & $243 \mathrm{~g}$ & $46 \mathrm{~g}$ \\
\hline A & Uric acid & $1.03 \mathrm{mg} / \mathrm{dl}$ & $0.176 \mathrm{mg} / \mathrm{dl}$ \\
\hline B & Weight & $262 \mathrm{~g}$ & $31 \mathrm{~g}$ \\
\hline B & Uric acid & $0.95 \mathrm{mg} / \mathrm{dl}$ & $0.295 \mathrm{mg} / \mathrm{dl}$ \\
\hline C & Weight & $212.5 \mathrm{~g}$ & $18 \mathrm{~g}$ \\
\hline C & Uric acid & $1.27 \mathrm{mg} / \mathrm{dl}$ & $0.457 \mathrm{mg} / \mathrm{dl}$ \\
\hline D & Weight & $210 \mathrm{~g}$ & $18 \mathrm{~g}$ \\
\hline D & Uric acid & $1.05 \mathrm{mg} / \mathrm{dl}$ & $0.201 \mathrm{mg} / \mathrm{dl}$ \\
\hline
\end{tabular}

Standard deviation: SD

Table 2: The increasing influence of U-74389G associated with reperfusion time.

\begin{tabular}{|l|l|l|l|l|}
\hline Alteration & $\mathbf{9 5 \%} \mathbf{c .}$ in. & $\begin{array}{l}\text { Reperfusion } \\
\text { time }\end{array}$ & t-test & GLM \\
\hline$+0.24 \mathrm{mg} / \mathrm{dl}$ & $\begin{array}{l}-0.085 \mathrm{mg} / \mathrm{dl} \\
-0.565 \mathrm{mg} / \mathrm{dl}\end{array}$ & $1 \mathrm{~h}$ & 0.184 & 0.138 \\
\hline$+0.17 \mathrm{mg} / \mathrm{dl}$ & $\begin{array}{l}-0.026 \mathrm{mg} / \mathrm{dl} \\
-0.366 \mathrm{mg} / \mathrm{dl}\end{array}$ & $1.5 \mathrm{~h}$ & 0.103 & 0.088 \\
\hline$+0.1 \mathrm{mg} / \mathrm{dl}$ & $\begin{array}{l}-0.137 \mathrm{mg} / \mathrm{dl} \\
-0.337 \mathrm{mg} / \mathrm{dl}\end{array}$ & $2 \mathrm{~h}$ & 0.401 & 0.388 \\
\hline$-0.15 \mathrm{mg} / \mathrm{dl}$ & $\begin{array}{l}-0.348 \mathrm{mg} / \mathrm{dl} \\
-0.048 \mathrm{mg} / \mathrm{dl}\end{array}$ & $\begin{array}{l}\text { reperfusion } \\
\text { time }\end{array}$ & 0.118 & 0.134 \\
\hline$+0.052 \mathrm{mg} / \mathrm{dl}$ & $\begin{array}{l}-0.069 \mathrm{mg} / \mathrm{dl} \\
-0.174 \mathrm{mg} / \mathrm{dl}\end{array}$ & interaction & & 0.387 \\
\hline
\end{tabular}

confidence interval: c. in;

Table 3: The (\%) alteration influence of U-74389G associated with reperfusion time.

\begin{tabular}{|l|l|l|l|}
\hline Alteration & \pm SD & Reperfusion time & p-values \\
\hline$+20.86 \%$ & $\pm 14.44 \%$ & $1 \mathrm{~h}$ & 0.161 \\
\hline$+15.43 \%$ & $\pm 9.10 \%$ & $1.5 \mathrm{~h}$ & 0.096 \\
\hline$+10 \%$ & $\pm 12.11 \%$ & $2 \mathrm{~h}$ & 0.394 \\
\hline$-13.61 \%$ & $\pm 9.18 \%$ & reperfusion time & 0.126 \\
\hline$+4.78 \%$ & $\pm 5.64 \%$ & interaction & 0.387 \\
\hline
\end{tabular}

liver, where most of it is converted to uric acid. Lazzarino G et al. found (13) significantly increased levels of SUA after cerebral IR in rats.

Although SUA predicts AIS and leads to gout, how renal SUA excretion is influenced by U-74389G is unknown. Moreover, only reperfusion time resulted in a non-significant decline of SUA levels, reflecting a non-significant increase in renal SUA excretion. All the other endpoints implicated by U-74389G administration exhibited discouraging but non-significant results. U-74389G increased SUA levels, reflecting a decrease in renal SUA excretion. This may stand for a generalized lack of amelioration of renal function by U-74389G administration. U-74389G 
cannot reverse the injury to IR tubular epithelial cells. If the injury is severe, death by apoptosis and necrosis (acute tubular necrosis) occur, with the functional impairment of water and electrolyte homeostasis and reduced excretion of metabolic waste products, including SUA. A longer study duration or a higher U-74389G dosage may reverse apoptosis and necrosis of tubular epithelial cells. The body mass, as mentioned above, had no impact on protocol; the most pronounced mass difference between the $\mathrm{B}$ and $\mathrm{D}$ groups ( $p$-value $=0.0004$ ) reflected a non-significant difference at their respective SUA levels ( $\mathrm{p}$-value $=0.4013$ ).

\section{CONCLUSION}

Whether it interacted with reperfusion time, U-74389G administration non-significantly increased SUA levels. U$74389 \mathrm{G}$ cannot reverse injury to IR tubular epithelial cells within 2 hours. Perhaps either a longer study time or a higher U-74389G dosage may reverse tubular apoptosis and prevent acute tubular necrosis.

Acknowledgements: This study was funded by the Scholarship by the Experimental Research Centre ELPEN Pharmaceuticals (E.R.C.E), Athens, Greece. The research facilities for this project were provided by the aforementioned institution.

\section{REFERENCES}

1. https://www.caymanchem.com/app/template/Product.vm/catalog/75860.

2. Shi F, Cavitt J, Audus LK. 21-aminosteroid and 2(aminomethyl) chromans inhibition of arachidonic acid-induced lipid peroxidation and permeability enhancement in bovine brain microvessel endothelial cell monolayers. Free Radic Biol Med. 1995;19:349-357.

3. Tsompos C, Panoulis C, Toutouzas K, Zografos G, Papalois A.: The Acute Effect Of The Antioxidant Drug "U-74389g" On Platelet Distribution Width During
Hypoxia Reoxygenation Injury In Rats. J Neurol Stroke 2015; 3(6): 00111. DOI: 10.15406/jnsk.2015.03.00111

4. Tsompos C, Panoulis C, Toutouzas K, Zografos G, Papalois A. Antioxidant 21-aminosteroid "U-74389G" ameliorates the short-time effect of hypoxia-reoxygenation on the platelet count in rats. Folia Med Cracov. 2015;55:25-34.

5. Flessas I, Bramis I, Menenakos E, et al. Effects of lazaroid U-74389G on intestinal ischemia and reperfusion injury in porcine experimental model. Int J Surg. 2014;28:42-8.

6. Bimpis A, Papalois A, Tsakiris S, et al. Activation of acetylcholinesterase after U-74389G administration in a porcine model of intracerebral hemorrhage. Metab Brain Dis. 2012;27:221-5.

7. Tsaroucha AK, Papalois A, Vernadakis S, et al. The effect of U-74389G on liver recovery after acute liver ischemia-reperfusion injury in a swine model. J Surg Res. 2009;151:10-4.

8. Andreadou I, Poussios D, Papalois A, et al. Effect of U74389G (21-lazaroid) on intestinal recovery after acute mesenteric ischemia and reperfusion in rats. In Vivo. 2003;17:463-8.

9. Chiquete E, Ruiz-Sandoval JL, Murillo-Bonilla LM, , et al. Serum uric acid and outcome after acute ischemic stroke: PREMIER study. Cerebrovasc Dis. 2013;35:168-74.

10. Logallo N, Naess H, Idicula TT, Brogger J, Waje-Andreassen U, Thomassen L. Serum uric acid: neuroprotection in thrombolysis. The Bergen NORSTROKE study. BMC Neurol. 2011;25:114.

11. Seifert J, Frelich A, Shecterle L, St Cyr J. Assessment of Hematological and Biochemical parameters with extended D-Ribose ingestion. J Int Soc Sports Nutr. 2008;15:13.

12. Hellsten-Westing Y, Kaijser L, Ekblom B, Sjödin B. Exchange of purines in human liver and skeletal muscle with short-term exhaustive exercise. Am J Physiol. 1994;266:81-6.

13. Lazzarino G, Vagnozzi R, Tavazzi B, et al. MDA, oxypurines, and nucleosides relate to reperfusion in shortterm incomplete cerebral ischemia in the rat. Free Radic Biol Med. 1992;13:489-98. 